\title{
"TATANIAGA DAN MARGIN PEMASARAN IKAN TUNA DI KOTA GORONTALO"
}

\author{
Di Susun
}

Oleh :

Miston Gunibala 1121418030

Cyndiana Putri 1121418024

Febriyanti Rasyid 1121418036

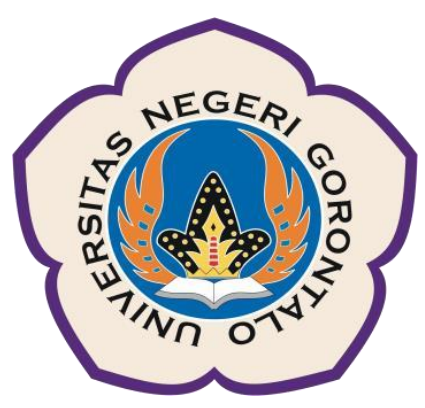

JURUSAN TEKNOLOGI HASIL PERIKANAN

FAKULTAS PERIKANAN DAN ILMU KELAUTAN UNIVERSITAS NEGERI GORONTALO 


\begin{abstract}
Abstrak
Penelitian ini membahas tentang margin pemasaran ikan tuna di kota gorontalo. Sampel yang digunakn pada penelitian ini sebanyak 16 nelayan aktif, pedagang pengumpul sebanyak 3 orang, pedagang pengecer sebanyak 15 orang, dan exportir 1 orang. Metode menggunakan purposive sampling. Analisis yang digunakan terdiri dari analisis pemasaran, analisis protif, analisis efisiensi pemasaran. Waktu penelitian dilakukan pada bulan Oktober-Desember tahun 2019, bertempat di Gorontalo, lembaga pemasaran ikan tuna.
\end{abstract}

\title{
PENDAHULUAN
}

Menurut kolter dan Amstrong (2002) saluran pemasaran merupakan tahapan organisasi yang terikat pada semua kegiatan untuk menyalurkan suatu produk kepada produsen. Pada umumnya dalam suatu usaha perikanan seperti sumberdaya Ikan Tuna, memiliki tahapan -tahapan berupa pra produksi, produksi, proses pengolahan sumber daya, sampai menuju tahapan pemasaran. Lembaga pemasaran berperan sebagai penentu saluran pemasaran meliputi, pembelian, sortasi, penyimpanan, pengangkutan. Pada lembaga pemasaran terdapat peran tertentu salah satunya lembaga pemasaran berperan sebagai tempat pedagang pengecer, keliling, dan pengumpul. Tetapi lembaga pemasaran tidak memiliki dan tidak menguasai barang seperti memfasiltasi pemasaran.

\section{METODE}

Penelitian ini melakukan metode survei untuk mengambil beberapa sampel dari satu populasi. Mendatangi objek penelitian yang meliouti, nelayan di tanjung kramat, jalur-jalur pemasaran, serta pelaku pemasaran dari pedagang pengecer, pedagang keliling, pedagang pegumpul. Metode purposive sampling, berupa pengambilan sampel kepada responden yang dipilih dan memiliki informasi berkaitan dengan tujuan penelitian. Pada metode analisis menggunakan margin pemasaran.

\section{HASIL DAN PEMBAHASAN}

Berdasarkan hasil pengamatan menggunakan metode survey mengatakan bahwa pedagang pengecer merupakan pedagang yang membeli ikan langsung dari nelayan (produsen) kemudian menjual ikannya langsung kepada konsumen. Harga penjualan ikan Tuna dari nelayan kepada pedagang pengecer adalah Rp 60.000/kg. Pedagang keliling ikan yaitu pedagang yang menggunakan kendaraan beroda dua (motor atau sepeda), dimana mereka membeli ikan dari nelayan, kemudian menjualnya kembali kepada konsumen. Harga penjualan ikan dari nelayan kepada pedagang keliling adalah Rp 70.000/kg. Kemudian Penelusuran pemasaran ikan Tuna di kota Gorontalo bahwa, pedagang pengumpul merupakan pedagang pemasaran yang hasil penjualan ikan Tunanya sampai keluar daerah seperti Bali, Palu, Makassar dan Surabaya. Harga penjualannya berkisar Rp 90.000/kg. Semakin jauh jarak antara produsen ke konsumen makin panjang saluran yang ditempuh oleh produk (Rohmatun, 2010). Sementara itu, Margin Pemasaran adalah Nilai keuntungan atau selisih harga yang diterima produsen dengan harga yang dibayarkan oleh konsumen. Dan margin pemasaran pada pedagang pengecer yaitu Rp.20.000, margin pemasaran pada pedagang keliling yaitu Rp.30.000 dan margin pemasaran pada pedagang pengumpul yaitu Rp.50.000. Dengan begitu harga pemasaran dengan margin tertinggi adalah pada pedagang pengumpul yaitu sebesar $55.56 \%$. 


\section{KESIMPULAN}

Kesimpulan yang dapat diambil dari jurnal kali ini yaitu pemasaran dengan margin tertinggi terdapat pada pedagang pengumpul yaitu sebesar $55.56 \%$.

\section{REFERENSI}

Yapanto, L. M., Salam, A., Hamzah, Z. Y. (2020). Tataniaga dan Margin Pemasaran Ikan Tuna di Kota Gorontalo. Jambura Journal Of Animal Science. E-Issn: 2855-2280 Volume 2 No. 2 Mei 2020. 